\title{
Recovery of the Alpine lynx Lynx lynx metapopulation
}

\author{
Anja Molinari-Jobin, Eric Marboutin, Sybille Wölfl, Manfred Wölfi \\ Paolo Molinari, Michael Fasel, Ivan Kos, Mateja BlažiČ \\ Christine Breitenmoser, Christian Fuxjäger, Thomas Huber \\ IZTOK KOREN and URS BREITENMOSER
}

\begin{abstract}
We use the case of the Eurasian lynx Lynx lynx in the Alps to discuss how to implement existing directives and recommendations, as well as how to integrate biological concepts, into practical conservation and wildlife management. Since 1995 the occurrence of lynx in the Alpine countries has been monitored and reported by the Status and Conservation of the Alpine Lynx Population expert group. Both the area of occupancy and the estimated number of individuals increased from 1995-1999 to 2000-2004. The estimated number of lynx is 120-150 across the Alps and the area of occupancy $27,800 \mathrm{~km}^{2}$, in six distinct sub-areas. In the highly fragmented Alpine habitat lynx populations expand slowly, even in situations of high local density and when suitable habitat is available. Thus, almost 40 years after the first reintroduction, $<20 \%$ of the Alps have been recolonized by lynx. In addition to biological and ecological factors, the persistent disagreements about the return of the lynx between conservationists and other land-users, including livestock breeders and hunters, and the political fragmentation of the Alps (with different regional priorities and large carnivore policies), has prevented the creation of a consensus regarding pan-Alpine conservation goals for the lynx and the implementation of conservation measures such as translo-
\end{abstract}

Anja Molinari-Jobin (Corresponding author) and Christine BreitenMOSER KORA, Thunstrasse 31, 3074 Muri, Switzerland. E-mail a.molinari@ kora.ch

ERIC Marboutin ONCFS, Gières, France.

SybilLE WöLfL Luchsprojekt Bayern, Lam, Germany.

MANFRED WÖLFL Bayerisches Staatsministerium für Umwelt und Gesundheit, München, Germany.

PaOlo Molinari Italian Lynx Project, Tarvisio, Italy.

Michael Fasel Ministry of Environmental Affairs, Land Use Planning, Agriculture and Forestry, Office of Forests, Nature and Land Management, Department of Nature and Landscape, Vaduz, Liechtenstein.

Ivan Kos University of Ljubljana, Ljubljana, Slovenia.

Mateja BlažIČ Environmental Agency of the Republic of Slovenia, Ministry for Environmental, Spatial Planning and Energy, Ljubljana, Slovenia.

Christian Fuxjäger NP OÖ Kalkalpen, Molln, Austria.

Thomas Huber Am Berg, Afritz, Austria.

Iztok Koren Slovenia Forest Service, Tolmin, Slovenia.

URS BReItenmoser Institute of Veterinary Virology, University of Berne, Bern, Switzerland.

Received 15 December 2008. Revision requested 9 March 2009. Accepted 29 April 2009. cations and reintroductions. We discuss possible approaches in the light of new guidelines for population level management plans for large carnivores recently developed on behalf of the European Commission.

Keywords Alps, distribution, Lynx lynx, metapopulation, population management, status

\section{Introduction}

The conservation of populations covering large areas and 1 across international boundaries often suffers from discrepancies between legal, biological and management units. International treaties and national laws define the legal status of species or subspecies. The biological units relevant for conservation, however, are populations or metapopulations, which may differ in regard to their status within a taxon's area or with respect to regulation. In addition, the administrative units where conservation or management measures need to be applied may only concern part of a population, leading to inconsistent management within a metapopulation.

Such problems are particularly difficult for the conservation of large carnivores, viable populations of which often have low densities across large areas and are usually transboundary. For example, 29 of 33 large carnivore populations identified in Europe lie across international boundaries (Linnell et al., 2008). However, intra-national regions are often autonomous regarding wildlife conservation and management, and thus there is often a discrepancy between the strict legal protection of large carnivores at the national or international level and the weak enforcement of preservation measures at regional or local levels.

In Europe the expanding populations of wolf Canis lupus, brown bear Ursus arctos and Eurasian lynx Lynx lynx are protected by the Council of Europe's Convention on the Conservation of European Wildlife and Natural Heritage (Bern Convention) and the European Union's Council Directive 92/43/EEC on the conservation of natural habitats and of wild fauna and flora (the Habitats Directive). After endorsement, these treaties must be implemented by national and regional legislation. Certain reservations against the full protection of the species are possible upon ratification but the countries must strive for, and maintain, a 
'favourable conservation status' of the species. Compilations of the species' legal and conservation status across Europe can be found in Boitani (2000) for the wolf, Swenson et al. (2000) for the brown bear, Breitenmoser et al. (2000) and von Arx et al. (2004) for the Eurasian lynx, and in the Species Online Information Systems at KORA (2009). Linnell et al. (2008) presented an exhaustive discussion of the relevant international treaties and their consequences for the management and conservation of large carnivores. The review was undertaken by the Large Carnivore Initiative for Europe (an IUCN/Species Survival Commission Working Group), upon the request of the European Commission, to provide guidelines for the conservation and management of large carnivores at the level of populations and metapopulations. The aim was to translate the legal framework into biological terms and to identify the requirements for matching local/ regional management and transboundary cooperation with legal and biological demands.

We use the case of the Eurasian lynx in the Alps to discuss how to implement existing directives and recommendations, and also how to integrate biological concepts into practical conservation and wildlife management. The Alps provide the largest continuous habitat suitable for large carnivores in Central and West Europe but they are also the world's most intensively used mountain range and are, with seven countries and five languages, highly fragmented, both culturally and administratively. However, the Alps provide an interesting case study of the reintegration of large carnivores into a cultivated landscape and of transboundary cooperation.

Lynx were earlier eradicated from the Alps but, since 1970, have been reintroduced in Switzerland, Slovenia, Austria and Italy (Breitenmoser \& Breitenmoser-Würsten, 2008). In 1995 the first pan-Alpine review of the status of the lynx took place (Breitenmoser-Würsten et al., 1998), giving rise to the Status and Conservation of the Alpine Lynx Population programme (KORA, 2009). Since then, lynx occurrences in the Alpine countries have been monitored and regularly reported by this programme. Here we (1) review the status and the development of the lynx populations in the Alps, (2) analyse the biological and anthropogenic factors supporting or impeding the conservation of the species, and (3) discuss the practical and conceptual requirements for the recovery of a well-established lynx metapopulation across the Alps.

\section{Methods}

The first country-based status reports reviewed the development of lynx populations from reintroductions in the 1970s until 1995 (Breitenmoser et al., 1998; Čop \& Frkovic, 1998; Huber \& Kaczensky, 1998; Kaczensky, 1998; Molinari, 1998; Ragni et al., 1998; Stahl \& Vandel, 1998). These reports instigated the synchronized assessment and reporting of the distribution and conservation status of lynx in the Alps (Fig. 1a). This joint approach revealed the need for a monitoring strategy with common data interpretation. Thus, common standards were defined for interpretation of the monitoring data (Molinari-Jobin et al., 2003), and this standardized interpretation was introduced in the second country-based status reports during 1995-1999 (Fig. 1b; Fasel, 2001; Huber et al., 2001; Molinari et al., 2001; Molinari-Jobin et al., 2001; Stahl \& Vandel, 2001; Staniša et al., 2001; Wölfl \& Kaczensky, 2001). The national status reports were then updated with data for 2000-2004 (Fasel, 2006; Koren et al., 2006; Laass et al., 2006; Marboutin et al., 2006; Molinari et al., 2006; Molinari-Jobin et al., 2006; Wölfl, 2006). The subsequent evaluation of population development and distribution of the lynx in the Alps was based on these status reports, in which the number and distribution of lynx signs collected within each country were presented.

We distinguish three categories of information in accordance with the guidelines of the Status and Conservation of the Alpine Lynx Population programme (Molinari-Jobin et al., 2003) based on the possibility of verifying the collected data. Category 1 data are reports of lynx killed or found dead, photographs of lynx, young orphaned lynx caught in the wild and placed in captivity, and scats that have been genetically identified. To improve comparability between countries we excluded photos of lynx obtained from camera trapping for capture-recapture estimations. Category 2 data are all records of livestock killed, wild prey remains and tracks reported by appropriately trained people. These records were mostly an objective proof of lynx presence. Category 3 data are all wild prey remains, scats and tracks reported by the general public as well as all sightings and vocalizations, i.e. all information that was not, or cannot be, directly verified. To estimate the extent of lynx occurrence we used a buffer of $5 \mathrm{~km}$ radius around Category 1 and 2 point data, resulting in an area of $c$. $80 \mathrm{~km}^{2}$ for each point, which corresponds approximately to average female home range size in the Alps (BreitenmoserWürsten et al., 2001). This is similar to the French system, in which each observation is given a buffer of an $81 \mathrm{~km}^{2}$ grid area of theoretical lynx presence made of nine $3 \times 3 \mathrm{~km}$ squares centred on the location (Vandel \& Stahl, 2005).

To distinguish specifically between outliers (isolated observations probably of floating individuals) and clusters (assembled observations indicating a closed population) we also described the population range of the lynx using the 95\% kernel area of the Category 1 and 2 data points (Worton, 1989; Seaman \& Powell, 1996), with a smoothing factor (also referred to as the bandwidth or h statistic, which controls how wide the probability mass is spread around a point and the smoothness or roughness of the density estimate) of 15,000 . We excluded data from the Slovenian southern subpopulation from all range analyses as it lies outside the Alps according to the definition of the Alpine Convention (Fig. 2). All spatial analyses were performed using the geographical information system ArcView v. 3.3 (ESRI, Redlands, USA). Regions referred to in the text are shown in Fig. 2. 

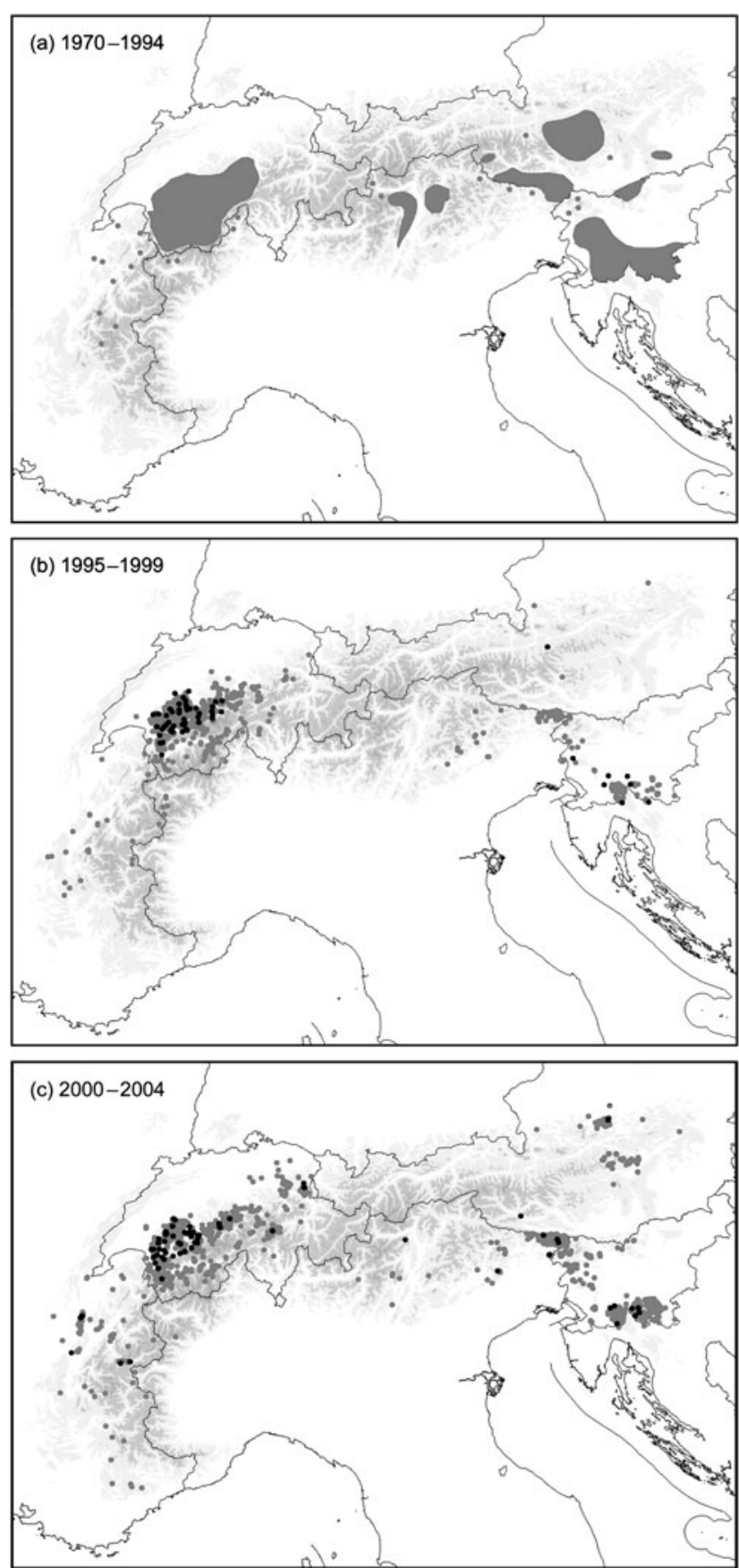

FIG. 1 Lynx Lynx lynx distribution in the Alps in (a) 1970-1994 (modified after Breitenmoser et al., 1998), (b) 1995-1999, and (c) 2000-2004. In (b) and (c) black and grey dots are Category 1 and 2 data, respectively (see text for further details).

\section{Results}

For the evaluation of the development of the Alpine lynx metapopulation we compared data collected during 20002004 with data from 1995-1999. In 2000-2004 a total of 3,742 lynx signs were collected, compared to 2,580 in $1995-1999$ (Table 1), and $69 \%$ of all signs recorded were in Categories 1 and 2 (Table 2). In Switzerland 30 dead lynx were reported

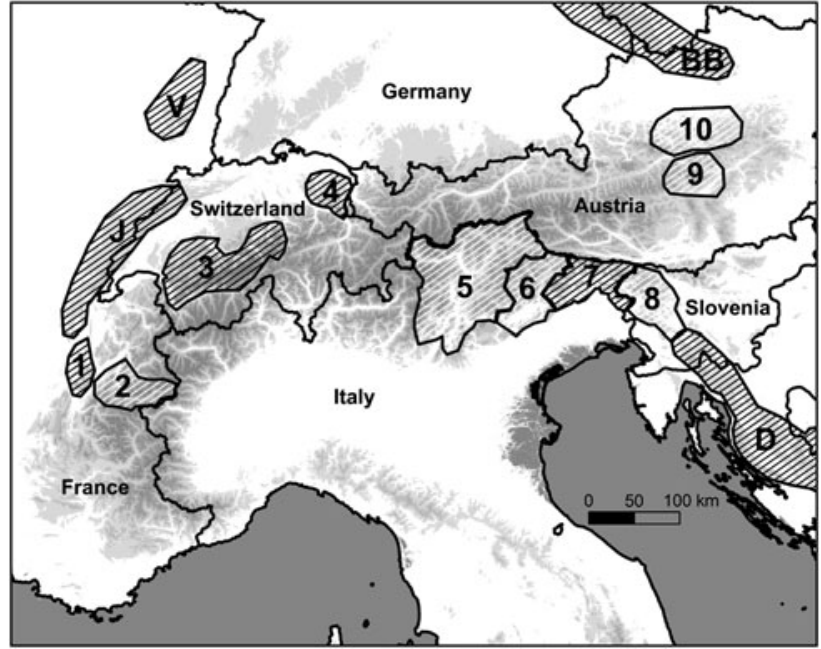

FIG. 2 Lynx populations and occurrence in the Alps as referred to in the text: 1, Chartreuse; 2, Maurienne; 3, north-west Alps; 4, north-east Switzerland; 5, Trentino Alto Adige; 6, Belluno; 7, Friuli; 8, Slovenian Alps; 9, Niedere Tauern; 10, Kalkalpen. The neighbouring lynx populations (von Arx et al., 2004) are: V, Vosges; J, Jura Mountains; D, Dinaric Mountains; BB, Bohemian Bavarian Forest. Black hatching indicates areas with confirmed lynx reproduction; white hatching areas without reported reproduction.

and six orphaned juveniles were removed from the population (Table 2). In Slovenia seven lynx were legally harvested, and in each of France and Austria one lynx was found dead. Most photos of lynx were from Switzerland, where many camera traps are used (e.g. to identify stock raiders). Livestock predation occurred in all countries where lynx are established, although the frequency varied from only two cases in Italy to 543 cases in Switzerland. The proportions of the various observation types were significantly different between countries $\left(\chi^{2}=1058.3, \mathrm{df}=12, \mathrm{P}<0.001\right.$, excluding Germany and Liechtenstein). In France $55 \%$ of all signs were from sightings, whereas in Austria $47 \%$ were from wild prey remains. Tracks made up $48 \%$ of all signs in Italy and $65 \%$ in Slovenia, whereas, in Switzerland, livestock predation, wild prey remains and sightings were reported with similar frequency. Whether these discrepancies are because of differences in monitoring systems or habitat features is not yet known.

In 2000-2004 the number of lynx signs was higher and the area occupied greater than in 1995-1999 (Table 1, Fig. 3). These increases were partly explained by increasing monitoring effort (Marboutin et al., 2006; Molinari et al., 2006). Nevertheless from 2000 to 2004 several additional isolated occurrences and range expansions occurred compared to 1995-1999 (Fig. 4). From the temporal and spatial distribution of lynx signs in the Austrian Kalkalpen National Park and the Niedere Tauern mountain range, Laass et al. (2006) concluded that more than one lynx occurs in both of these 
TABLE 1 Number of lynx Lynx lynx signs collected in each alpine country, by Category (see text for further details) and for 1995-1999 and 2000-2004.

\begin{tabular}{|c|c|c|c|c|c|c|c|c|}
\hline & France & Italy & Switzerland & Liechtenstein & Austria & Germany & Slovenia & Total \\
\hline \multicolumn{9}{|l|}{ 1995-1999 } \\
\hline Category 1 & & & 49 & & 1 & & 13 & 63 \\
\hline Category 2 & 7 & 85 & 1,115 & & 5 & & 307 & 1,519 \\
\hline Category 3 & 62 & 176 & 469 & & 100 & 6 & 185 & 998 \\
\hline Total & 69 & 261 & 1,633 & & 106 & 6 & 505 & 2,580 \\
\hline \multicolumn{9}{|l|}{ 2000-2004 } \\
\hline Category 1 & 3 & 6 & 160 & & 5 & & 7 & 181 \\
\hline Category 2 & 88 & 226 & 1,227 & & 104 & & 754 & 2,399 \\
\hline Category 3 & 111 & 179 & 608 & 1 & 115 & 1 & 147 & 1,162 \\
\hline Total & 202 & 411 & 1,995 & 1 & 224 & 1 & 908 & 3,742 \\
\hline
\end{tabular}

areas. In Switzerland the translocation of a total of 12 lynx to the north-east in 2001-2008 (Ryser et al., 2004; A. Ryser, unpubl. data), led to an Alps-wide $7 \%$ increase in the area occupied. Lynx signs in France are generally scattered but are more concentrated in the Chartreuse region close to the Jura Mountains and Maurienne (Marboutin et al., 2006), and new observations have been reported (Marboutin et al., 2006) from the southern French Alps, indicating a possible southward expansion that still needs to be confirmed.

More than half of the signs were collected in Switzerland, although Switzerland only contains 15\% of the Alps (Bätzing, 1997). A kernel analysis of all signs illustrated that the most important area for lynx is in the north-western Alps (western Switzerland). There is a second nucleus in the south-eastern
Alps (Italy and Slovenia), and four other areas of similar size (Fig. 4). However, reproduction has only been reported in four areas: the north-western Alps (Molinari-Jobin et al., 2006), Friuli (Molinari et al., 2006), north-eastern Switzerland (Ryser et al., 2004) and the Chartreuse region (Michallet, 2004). There is no permanent lynx presence with reproduction between or outside these areas, and even single confirmed observations are rare (Fig. 1c).

In Italy the 2000-2004 data indicate a contiguous population from north-eastern Friuli to the province of Belluno (Molinari et al., 2006). In addition, lynx were confirmed in the Trentino Alto Adige region, where lynx had been present in the 1980s (Ragni et al., 1998) but not in 1995-1999. More signs of lynx were reported from the Slovenian Alps in

TABLE 2 Number of lynx signs collected in each alpine country, by Category (see text for further details), during $2000-2004$.

\begin{tabular}{|c|c|c|c|c|c|c|c|c|}
\hline & France & Italy & Switzerland & Liechtenstein & Germany & Austria & Slovenia & Total \\
\hline \multicolumn{9}{|l|}{ Category 1} \\
\hline Lynx found dead & 1 & & 18 & & & 1 & & 20 \\
\hline Killed (livestock raider) & & & 3 & & & & & 3 \\
\hline Illegally killed & & & 9 & & & & & 9 \\
\hline Lynx harvested & & & & & & & 7 & 7 \\
\hline Lynx removed $^{1}$ & & & 6 & & & & & 6 \\
\hline Photo & 2 & 4 & $124^{2}$ & & & 2 & & 132 \\
\hline Scats $^{3}$ & & 2 & & & & 2 & & 4 \\
\hline Total & 3 & & 160 & & & 5 & 7 & 181 \\
\hline \multicolumn{9}{|l|}{ Category 2} \\
\hline Livestock killed & 13 & 2 & 543 & & & 7 & 122 & 687 \\
\hline Wild prey remains & 23 & 64 & 449 & & & 49 & 143 & 728 \\
\hline Tracks & 52 & 160 & 235 & & & 48 & 489 & 984 \\
\hline Total & 88 & 226 & 1,227 & & & 104 & 754 & 2,399 \\
\hline \multicolumn{9}{|l|}{ Category 3} \\
\hline Wild prey remains & & 39 & 61 & & & 56 & 23 & 179 \\
\hline Tracks & & 35 & 72 & & & 23 & 103 & 233 \\
\hline Sightings & 111 & 97 & 444 & 1 & 1 & 31 & 21 & 706 \\
\hline Vocalizations & & 3 & 20 & & & 4 & & 27 \\
\hline Scats & & 5 & 11 & & & 1 & & 17 \\
\hline Total & 111 & 179 & 608 & 1 & 1 & 115 & 147 & 1,162 \\
\hline
\end{tabular}

${ }^{1}$ Mainly young orphaned lynx captured and placed in captivity

${ }^{2}$ An additional 97 photos were taken during camera trapping to estimate lynx density

${ }^{3}$ Scats that have been genetically identified 


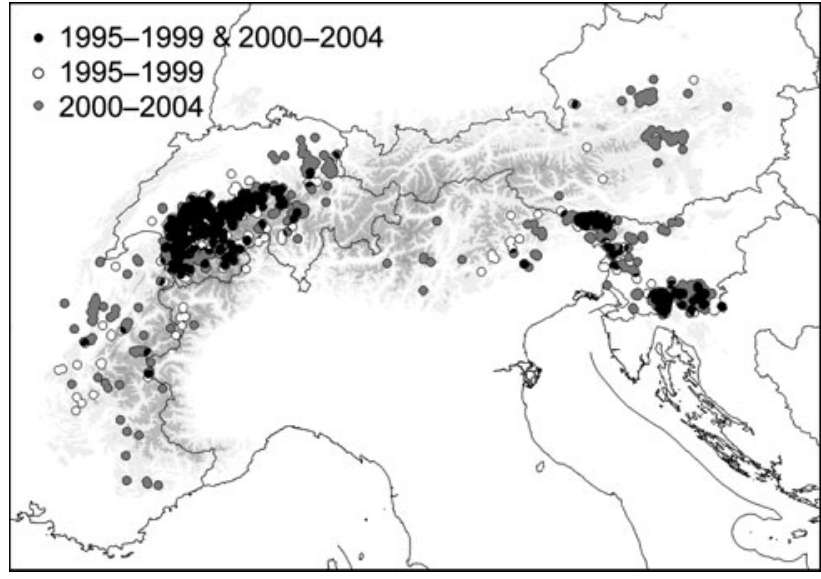

Fig. 3 Development of lynx distribution from 1995-1999 to 2000-2004 (black, area occupied during both periods; white, area occupied during 1995-1999 only; grey, area occupied during 2000-2004 only). Each dot represents a point observation buffered with a radius of $5 \mathrm{~km}$ (see text for further details).

2000-2004 than in 1995-1999 (Koren et al., 2006) and, based on the kernel method, the area occupied in the northwestern Alps increased from 9,714 $\mathrm{km}^{2}$ in 1995-1999 to $14,395 \mathrm{~km}^{2}$ in 2000-2004, (Fig. 4). Finally, after $>100$ years of absence, the first sign of lynx was reported from Liechtenstein in 2004 (Fasel, 2006) but no signs of lynx were reported from the German Alps (Wölfl, 2006).

The $5-\mathrm{km}$ buffer method suggests that the total area of lynx distribution increased from $13,870 \mathrm{~km}^{2}$ in $1995-1999$ to $20,650 \mathrm{~km}^{2}$ in $2000-2004$, whereas the $95 \%$ kernel method indicates that the area of lynx distribution increased from 11,000 to $27,790 \mathrm{~km}^{2}$. For $2000-2004$ the number of independent lynx was estimated to be 60-90 in the Swiss Alps (Molinari-Jobin et al., 2006), $<20$ in both the French (Marboutin et al., 2006) and Italian Alps (Molinari et al., 2006), 15 in the Slovenian Alps (Koren et al., 2006) and at least four in Austria (Laass et al., 2006), giving a total of 120150 across the Alps. This compares to an estimated 90-120 across the Alps in 1995-1999 (Molinari-Jobin et al., 2003). Unfortunately a comparison with data before 1995 is not possible as point observations were not then available (Fig. 1a). KORA (2009) gives an update of the development of the metapopulation for the years 2005-2007.

\section{Discussion}

Combined interpretation and reporting of monitoring data are crucial for the assessment of the status of a lynx population stretching over several countries. We have demonstrated that, as long as data comparability is assured through a standardization process, it is possible to monitor the status of lynx consistently over a large area, heterogeneous landscapes and several countries with differing wildlife management systems. With a common terminology, assessment and
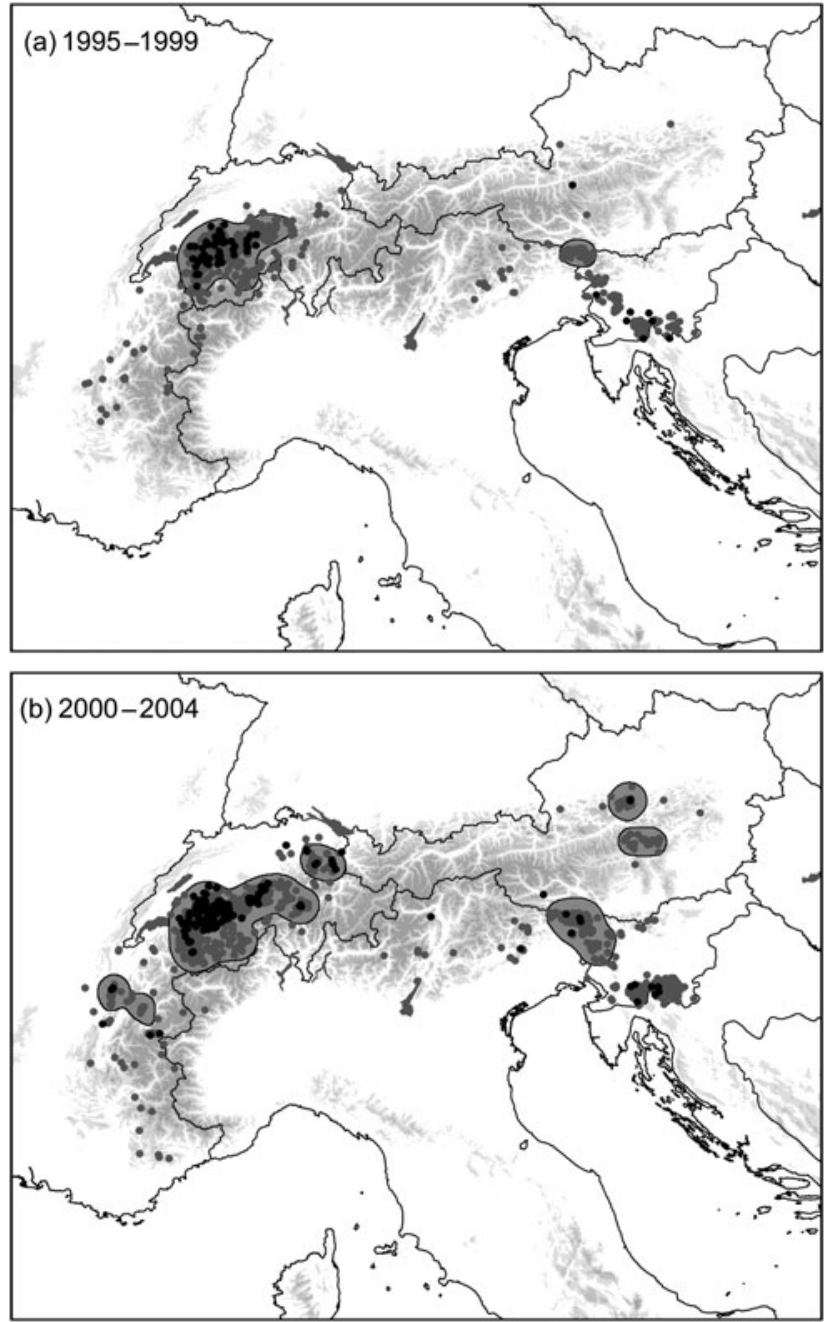

Fig. 4 Lynx occurrences in the Alps (the grey shaded area surrounded by a black line is the 95\% kernel area) in (a) 19951999 and (b) 2000-2004. Black and grey dots are Category 1 and 2 data, respectively (see text for further details).

data interpretation, we ensured data comparability. It is, nevertheless, difficult to estimate the area occupied in a highly fragmented area such as the Alps, where suitable lynx habitat (mainly well-forested areas) is interspersed with high alpine zones and densely populated valleys.

The uneven density of point observations may not only indicate differences in the number of lynx present but may also reflect monitoring effort. We thus used two different methods for estimation of the occupied area. The buffer method overestimates the area of permanent presence because it treats observations of transient lynx the same as observations of resident individuals. The kernel method results in a possible distortion of the area occupied because the more data collected in a given area, the more weight that area receives. Despite these biases, however, both methods showed a greater area occupied in 2000-2004 than in 1995-1999. Over the same period the estimated number of individual lynx increased by c. $30 \%$. Thus, although these estimates are not 
fully independent (numbers being partly deduced from areas), it appears that both the area of occupancy and the number of individuals increased.

The largest Alpine subpopulation, in the north-western Alps, has about the same number of lynx as the neighbouring populations in the Dinaric and Jura Mountains and the Bohemian-Bavarian Forest (Fig. 2). These reintroduced populations were all founded at least 25 years ago and each now has 75-130 mature individuals (Wölfl et al., 2001; von Arx et al., 2004; Capt, 2007; Marboutin et al., 2008).

Lynx elsewhere in the Alps are few, sometimes only single individuals, and recolonization seems to have advanced extremely slowly. In the highly fragmented Alps, with many natural and anthropogenic barriers, lynx have proven to be poor colonizers. Although some of the isolated individuals may be the result of long-range dispersal, the average dispersal rate and distance is low in the Alps compared, for example, to Scandinavia (Andersen et al., 2003). Almost 40 years after the first reintroduction $<20 \%$ of the Alps have been recolonized, despite considerable efforts at the international level to expand existing lynx areas (Table 3 ). However, we do not yet know the natural expansion capacity of lynx in a fragmented landscape such as the Alps.

All Alpine countries are signatories of the Bern Convention, and all but Liechtenstein and Switzerland of the Habitat Directives of the European Union, and thus have the legal obligation to conserve wild flora and fauna. However, lynx have not reached 'favourable conservation status' anywhere in the Alps and the Alpine metapopulation as a whole is still fragmented. Both the Habitats Directive, in the Guidelines for Population Level Management Plans for Large Carnivores (Linnell et al., 2008) and the Bern Convention (Recommendation 115/2005), emphasize the importance of cross-border cooperation in the conservation and management of large carnivore populations. As two Alpine countries are not members of the EU, the Bern Convention of the Council of Europe provides the only international framework for lynx conservation across the Alps. The Bern Convention released several recommendations regarding the lynx and endorsed the Pan-Alpine Conservation Strategy for the Lynx in 2001 (Molinari-Jobin et al., 2003; Table 3). The Strategy was developed by the Status and Conservation of the Alpine Lynx Population expert group to provide conceptual guidance for the recovery of a viable lynx metapopulation across the Alps but has so far only been implemented in Switzerland (Table 3), where a management plan was put into practice (Blankenhorn, 2003) and the expansion of the population was supported through translocations (Ryser et al., 2004).

The implementation of active conservation measures in the range countries, even if they are implicitly or explicitly demanded by international treaties, is hampered by three factors. Firstly, there are different priorities regarding large carnivore policy. In Switzerland and parts of Slovenia lynx problems locally ranked high on the political agenda but the
TABLE 3 Chronology of lynx conservation in the Alps.

\begin{tabular}{|c|c|}
\hline Period & Event \\
\hline 1970s & $\begin{array}{l}\text { Reintroductions in Switzerland, Slovenia, } \\
\text { Austria \& Italy }\end{array}$ \\
\hline 1978 & Turrach symposium (organized by Festetics) \\
\hline 1993 & $\begin{array}{l}\text { Formation of the Status and Conservation of } \\
\text { the Alpine Lynx Population programme } \\
\text { expert group (see text for further details) }\end{array}$ \\
\hline 1995 & $\begin{array}{l}\text { Engelberg symposium (organised by the Status and } \\
\text { Conservation of the Alpine Lynx Population } \\
\text { programme under the auspices of the Council } \\
\text { of Europe) }\end{array}$ \\
\hline 2000 & $\begin{array}{l}\text { Action plan for the conservation of the Eurasian } \\
\text { lynx in Europe (on behalf of the Large Carnivore } \\
\text { Initiative for Europe) }\end{array}$ \\
\hline 2000 & Swiss Lynx Management Plan \\
\hline 2001 & $\begin{array}{l}\text { Pan-Alpine Conservation Strategy for the Lynx } \\
\text { (drafted by the Status and Conservation of the } \\
\text { Alpine Lynx Population programme, endorsed by } \\
\text { the Standing Committee of the Bern Convention) }\end{array}$ \\
\hline 2003 & $\begin{array}{l}\text { Amden symposium (organized by the Status and } \\
\text { Conservation of the Alpine Lynx Population } \\
\text { programme, under the auspices of the Council } \\
\text { of Europe) }\end{array}$ \\
\hline 2005 & $\begin{array}{l}\text { Recommendation No. } 115 \text { of the Bern Convention } \\
\text { on the conservation \& management of } \\
\text { transboundary populations of large carnivores }\end{array}$ \\
\hline $\begin{array}{l}2001- \\
2008\end{array}$ & $\begin{array}{l}\text { Translocations of } 12 \text { lynx to north-eastern } \\
\text { Switzerland as a consequence of the Swiss } \\
\text { Lynx Management Plan }\end{array}$ \\
\hline 2008 & $\begin{array}{l}\text { Recommendation No. } 137 \text { of the Standing } \\
\text { Committee of the Bern Convention on population } \\
\text { level management of large carnivore populations }\end{array}$ \\
\hline
\end{tabular}

brown bear had higher priority than the wolf and lynx in Austria, the Italian provinces in the Eastern Alps and, recently, in southern Germany, and the wolf was the main challenge for France and in the western Italian Alps. Secondly, there is a lack of capacity and political means at the national level in federal countries, where regional institutions are the wildlife management authorities. Thirdly, there is a fear of triggering conflicts with land users such as hunters and livestock breeders over the return of lynx.

There are several reasons for the slow expansion of the lynx populations in the Alps, all associated with threats to the survival of individuals or subpopulations. We performed a threat analysis based on our joint experience and personal assessments (Table 4). We considered local habitat quality per se to be of little concern at present and in the near future compared to fragmentation of the habitat by barriers. The Alps are naturally and artificially fragmented. Highways act as boundaries between lynx home ranges or separate subpopulations and thus limit exchange of individuals (Breitenmoser-Würsten et al., 2001). Although individual lynx can overcome almost any obstacle, for the population to 
TAble 4 Assessment of identified and potential threats to the lynx population in the Alps by seven of the authors, and conservation actions recommended. We judged the threats independently according to the following scale: 1, not a risk for the lynx population at present or in the near future; 3 , identified cause of individual losses but not a threat to the population on its own; 5 , a potential risk at the population level; 2 and 4 are intermediate levels. Mean assessment (and range) is for $\mathrm{n}=7$. For further details of the actions recommended, see the text.

\begin{tabular}{|c|c|c|c|}
\hline Threat & Mean assessment (range) & Rank & Actions recommended \\
\hline \multicolumn{4}{|l|}{ Resource depression } \\
\hline Habitat deterioration & $1.7(1-3)$ & 7.5 & $\begin{array}{l}\text { Channel tourism to certain areas to provide } \\
\text { wildlife refuge zones }\end{array}$ \\
\hline Fragmentation & $3.1(1-4)$ & 2 & $\begin{array}{l}\text { Landscape restoration to mitigate barriers; } \\
\text { green bridges, underpasses }\end{array}$ \\
\hline Prey decline & $2.1(1-4)$ & 5 & Sustainable management of prey populations \\
\hline Competition with wolf & $1.6(1-2)$ & 9 & None \\
\hline \multicolumn{4}{|l|}{ Anthropogenic losses } \\
\hline Hunting & $1.3(1-3)$ & 10 & $\begin{array}{l}\text { Improve monitoring to guarantee } \\
\text { sustainability }\end{array}$ \\
\hline Illegal killing & $3.9(1-5)$ & 1 & $\begin{array}{l}\text { Conflict management; legal sustainable } \\
\text { hunting to reduce impact on game; } \\
\text { compensation, removal of stock raiders }\end{array}$ \\
\hline Anthropogenic accidents & $2.7(1-4)$ & 3 & Collect more data \\
\hline \multicolumn{4}{|c|}{ Natural factors/population viability } \\
\hline Disease & $1.8(1-3)$ & 6 & Surveillance \\
\hline Demographic viability & $2.6(1-4)$ & 4 & $\begin{array}{l}\text { Research projects to obtain more field } \\
\text { estimates of key parameters }\end{array}$ \\
\hline Genetic viability/inbreeding & $1.7(1-3)$ & 7.5 & $\begin{array}{l}\text { Establish standardized genetic monitoring; } \\
\text { translocations if needed }\end{array}$ \\
\hline
\end{tabular}

spread across such a barrier and to settle on the other side a relatively high input, with repeated immigration from the source population, seems to be needed. Prey availability is probably not a limiting factor for re-colonization. However, locally high lynx abundance can lead to a depression of the main prey species, roe deer Capreolus capreolus and chamois Rupicapra rupicapra, leading subsequently to natural decreases in the lynx population and, as a consequence of conflict, illegal killing (Breitenmoser et al., in press). Although confirmed information is limited, illegal killing occurs in all populations and was ranked first in our assessment (Table 4 ). Managing this conflict with traditional land users is the key to lynx conservation. Lynx kill few livestock compared with other large carnivore species, and compensation and removal of problem individuals effectively mitigates this conflict (Stahl et al., 2001; Breitenmoser \& BreitenmoserWürsten, 2008).

The crucial conflict, however, is with hunters, who compete with lynx for game, and who fear that increased lynx abundance, or even their presence, diminishes ungulate game (Table 4). Resistance from hunters to the return of this potential competitor not only leads to illegal killing but is also the reason why regional authorities are reluctant to become involved in active conservation. Hence the mitigation of this conflict may also help to overcome the political deadlock.

A possible solution, which has been proposed by hunters' associations and wildlife managers, may be a controlled legal harvest of lynx to suppress uncontrolled and unmanageable illegal killing. Conservationists are opposed to such a solution because they fear undermining the strict legal protection and argue that there is no proof that a legal harvest will halt illegal killing. Andrén et al. (2006) observed that illegal killing also occurred in regions in Scandinavia where a legal harvest is allowed. They observed a negative correlation between the harvest quota and the number of lynx killed illegally but this correlation was not consistent for all study areas. Legal protection of lynx in central and eastern European countries, when they became members of the European Union and enacted the Habitats Directive, did not lead to population increases (Gregorová et al., 2001; Okarma \& Olszanska, 2001). We assume that strict legal protection of a conflict species such as lynx on a national or international level does generally not encourage local or regional politicians and administrators to implement conservation actions, as they do not have the authority to intervene when lynx abundance increases above a level tolerated by local land users.

The recovery of the lynx in the Alps requires an agreement on the long-term goals for the entire Alpine arc and the commitment of all countries. This, however, is not possible without an agreement at the national level with the appropriate administrative units. The approval of active conservation measures, such as translocations or reintroductions, by the subunits will depend on a consensus amongst regional, and even local, interest groups, which implies their 
involvement in the planning process and an agreement not only on conservation but also on possible control measures. In the Alps, with its high cultural and administrative diversity, this is a difficult political and practical challenge. A new opportunity to start this process is offered by the Guidelines for Population Level Management Plans for Large Carnivores (Linnell et al., 2008), initiated by the European Commission to encourage countries sharing potential populations of large carnivores to develop mutual and transboundary management plans. Cooperation with neighbours will give greater management flexibility and freedom (Linnell et al., 2008). The total expanse of habitat suitable for the recovery of lynx in many countries is too small to host a viable population. However, if the metapopulation can be managed across international borders 'favourable conservation status' could be obtained and cooperating countries will gain a certain flexibility in regard to local management decisions.

Finally, is an active approach to conservation of the lynx in the Alps needed? The most difficult parameter to assess in the recovery of a species or population is time. Thirty years may not have been sufficient for lynx populations to spread further than what has so far been observed. However, we have noted several local fluctuations in numbers, each time leading to undesirable management conflicts, without an obvious expansion of the respective population. All reintroduced populations are based on a few founder individuals (Breitenmoser \& Breitenmoser-Würsten, 2008), and a considerable reduction of their genetic diversity through inbreeding and genetic drift is already obvious (BreitenmoserWürsten \& Obexer-Ruff, 2005). Proactive measures for conservation and management of the lynx in the Alps seem to be the best solution for both the problems of the lynx and the problems with the lynx. The Status and Conservation of the Alpine Lynx Population expert group has established common monitoring principles across the Alps and will continue monitoring the development of the metapopulation. What is now needed, however, is a political commitment for the recovery of the Alpine lynx population, and this seems to be possible only if a compromise between the interest groups, mainly conservation organizations and hunters, can be achieved.

\section{Acknowledgements}

We thank all the governmental and non-governmental organizations, universities and people who have collaborated with the Status and Conservation of the Alpine Lynx Population programme to monitor the lynx in the Alps (for a complete list of partners see KORA, 2009). We are also grateful to Dan Ward for help with English. In recent years the Status and Conservation of the Alpine Lynx Population programme has been financially supported by WWF Switzerland and the MAVA Foundation.

\section{References}

Andersen, R., Linnell, J.D.C., Odden, J., Andrén, H., SÆther, B.E., MoA, P.F. et al. (2003) Utredninger i forbindelse med ny rovviltmelding. Gaupe-bestandsdynamikk, bestandsutvikling og høstingsstrategier. NINA Fagrapport, 59, 1-28.

Andrén, H., Linnell, J.D.C., Liberg, O., Andersen, R., Danell, A., Karlsson, J. et al. (2006) Survival rates and causes of mortality in Eurasian lynx (Lynx lynx) in multi-use landscapes. Biological Conservation, 131, 23-32.

ВётZıNG, W. (1997) Kleines Alpen-Lexikon: Umwelt, Wirtschaft, Kultur. Beck, Munich, Germany.

Blankenhorn, H.J. (2003) The Swiss Lynx Management Plan. Second conference on the status and conservation of the Alpine lynx population (SCALP). Environmental Encounters, 58, 69-71.

Boitani, L. (2000) Action plan for the conservation of wolves in Europe (Canis lupus). Nature and Environment, 113, 1-85.

Breitenmoser, U. \& Breitenmoser-Würsten, C. (2008) Der Luchs-ein Grossraubtier in der Kulturlandschaft. Salm Verlag, Bern, Switzerland.

Breitenmoser, U., Breitenmoser-Würsten, C. \& Capt, S. (1998) Reintroduction and present status of the lynx (Lynx lynx) in Switzerland. Hystrix, 10, 17-30.

Breitenmoser, U., Breitenmoser-Würsten, C., Okarma, H., Kaphegyi, T., Kaphegyi-Wallmann, U. \& Müller, U.M. (2000) Action plan for the conservation of the Eurasian lynx (Lynx lynx) in Europe. Nature and Environment, 112, 1-70.

Breitenmoser, U., Ryser, A., Molinari-Jobin, A., Zimmermann, F., Haller, H., Molinari, P. \& BreitenmoserWÜRSTEN, C. (in press) Changing predation impact as a source of conflict with reintroduced lynx in Switzerland. In Biology and Conservation of Wild Felids (eds D.W. Macdonald \& A.J. Loverdige). Oxford University Press, Oxford, UK.

Breitenmoser-Würsten, C. \& Obexer-Ruff, G. (2005) Population and conservation genetics of two re-introduced lynx (Lynx lynx) populations in Switzerland-a molecular evaluation 30 years after translocation. Environmental Encounters, 58, 51-56.

Breitenmoser-Würsten, C., Rohner, C. \& Breitenmoser, U. (1998) The reintroduction of the lynx into the Alps. Environmental Encounters, 38, 1-157.

Breitenmoser-Würsten, C., Zimmermann, F., Ryser, A., Capt, S., Laass, J., Siegenthaler, A. \& Breitenmoser, U. (2001) Untersuchungen zur Luchspopulation in den Nordwestalpen der Schweiz 1997-2000. KORA Bericht no. 9. KORA, Muri, Switzerland.

CA T, S. (2007) Monitoring and present status of the lynx Lynx lynx in the Jura Mountains. Wildlife Biology, 13, 356-364.

Čop, J. \& Frkovic, A. (1998) The re-introduction of lynx in Slovenia and its present status in Slovenia and Croatia. Hystrix, 10, 65-76.

Fasel, M. (2001) The lynx in Liechtenstein. Hystrix, 12, 29.

FASEL, M. (2006) The lynx in Liechtenstein. Acta Biologica Slovenica, $49,53-54$

Gregorová, E., Pilinsky, P., Hell, P. \& Valach, I. (2001) Slovakia. In Status and Conservation of the Eurasian Lynx (Lynx lynx) in Europe in 2001 (eds M. von Arx, C. BreitenmoserWürsten, F. Zimmermann \& U. Breitenmoser), pp. 176-183. KORA Bericht no. 19. KORA, Muri, Switzerland.

Huber, T. \& KaCZensky, P. (1998) The situation of the lynx (Lynx lynx) in Austria. Hystrix, 10, 43-54.

Huber, T., Laass, J. \& Engleder, T. (2001) Present knowledge on the distribution of the lynx (Lynx lynx) in Austria. Hystrix, 12, $31-37$.

KaCZenSKy, P. (1998) Present status and distribution of the lynx in the German Alps. Hystrix, 10, 39-42. 
KORA (2009) Http://www.kora.ch [accessed 30 September 2009].

Koren, I., Jonozovič, M. \& Kos, I. (2006) Status and distribution of the Eurasian lynx (Lynx lynx L.) in Slovenia in 2000-2004 and comparison with the years 1995-1999. Acta Biologica Slovenica, 49, $27-41$.

Laass, J., Fuxjäger, C., Huber, T. \& Gerstl, N. (2006) Lynx in the Austrian Alps 2000 to 2004. Acta Biologica Slovenica, 49, 43-49.

Linnell, J.D.C., Salvatori, V. \& Boitani, L. (2008) Guidelines for Population Level Management Plans for Large Carnivores in Europe. A Large Carnivore Initiative for Europe report prepared for the European Commission (contract 070501/2005/424162/ $\left.\mathrm{MAR} / \mathrm{B}_{2}\right)$.

Marboutin, E., Duchamp, C., Catusse, M., Leger, F., Léonard, Y., Boyer, J. et al. (2008) Le suivi du statut de conservation de la population de lynx en France: bilan pour la période triennale 2005-2007. Bulletin du Réseau Lynx, 14, 20-27.

Marboutin, E., Duchamp, C., Rouland, P., Léonard, Y., Boyer, J., Catusse, M. et al. (2006) Survey of the lynx distribution in the French Alps: 2000-2004 population status analysis. Acta Biologica Slovenica, 49, 19-26.

Michallet, J. (2004) Chartreuse Iséroise: reproduction du lynx attestée en 2003. Bulletin du Réseau Lynx, 10, 8.

Molinari, P. (1998) The lynx in the Italian South-eastern Alps. Hystrix, 10, 55-64.

Molinari, P., Bionda, R., Carmignola, G., Catello, M., Cetto, E., Filacorda, S. et al. (2006) Status of the Eurasian lynx (Lynx lynx) in the Italian Alps: an overview 2000-2004. Acta Biologica Slovenica, 49, 13-18.

Molinari, P., Rotelli, L., Catello, M. \& Bassano, B. (2001) Present status and distribution of the Eurasian lynx (Lynx lynx) in the Italian Alps. Hystrix, 12, 3-10.

Molinari-Jobin, A., Molinari, P., Breitenmoser-Würsten, C., Wölfl, M., St anisa, C., Fasel, M. et al. (2003) Pan-alpine conservation strategy for the lynx. Nature and Environment, 130, 1-20.

Molinari-Jobin, A., Zimmermann, F., Angst, C., Breitenmoser-Würsten, C., Capt, S. \& Breitenmoser, U. (2006) Status and distribution of the lynx in the Swiss Alps 2000-2004. Acta Biologica Slovenica, 49, 3-11.

Molinari-Jobin, A., Zimmermann, F., BreitenmoserWürsten, C., Capt, S. \& Breitenmoser, U. (2001) Present status and distribution of the lynx in the Swiss Alps. Hystrix, 12, $17-28$.

Okarma, H. \& Olszanska, A. (2001) Poland. In Status and Conservation of the Eurasian Lynx (Lynx lynx) in Europe in 2001 (eds M. von Arx, C. Breitenmoser-Würsten, F. Zimmermann \& U. Breitenmoser), pp. 154-160. KORA Bericht no. 19. KORA, Muri, Switzerland.

Ragni, B., Possenti, M., Mayr, S., Carrer, M., Zangrando, E., Catello, M. et al. (1998) The lynx in the Italian Alps. Hystrix, 10, 31-38.

Ryser, A., von Wattentyl, K., Ryser-Degiorgis, M.P., Willisch, C., Zimmermann, F. \& Breitenmoser, U. (2004) Luchsumsiedlung Nordostschweiz 2001-2003: Schlussbericht Modul Luchs des Projektes LUNO. KORA Bericht no. 22. KORA, Muri, Switzerland.
Seaman, D.E. \& Powell, R.A. (1996) An evaluation of the accuracy of kernel density estimators for home range analysis. Ecology, 77, 2075-2085.

Stahl, P. \& Vandel, J.M. (1998) Distribution of the lynx in the French Alps. Hystrix, 10, 3-16.

Stahl, P. \& VAndel, J.M. (2001) Lynx distribution in the French Alps (1995-1999). Hystrix, 12, 11-16.

Stahl, P., Vandel, J.M., Herrenschmidt, V. \& Migot, P. (2001) The effect of removing lynx in reducing attacks on sheep in the French Jura Mountains. Biological Conservation, 101, 15-22.

Staniša, C., Koren, I. \& Adamič, M. (2001) Situation and distribution of the lynx (Lynx lynx L.) in Slovenia from 1995-1999. Hystrix, 12, 43-51.

Swenson, J.E., Gerstl, N., Dahle, B. \& Zedrosser, A. (2000) Action plan for the conservation of the brown bear in Europe (Ursus arctos). Nature and Environment, 114, 1-69.

VANDEL, J.M. \& STAHL, P. (2005) Distribution trend of the Eurasian lynx (Lynx lynx) populations in France. Mammalia, 69, 145-158.

von Arx, M., Breitenmoser-Würsten, C., Zimmermann, F. \& Breitenmoser, U. (2004) Status and Conservation of the Eurasian Lynx (Lynx lynx) in Europe in 2001. KORA Bericht no. 19. KORA, Muri, Switzerland.

Wölfl, M. (2006) Present status and distribution of the lynx in the German Alps 2000-2004. Acta Biologica Slovenica, 49, 51-52.

Wölfl, M., Bufka, L., Cerveny, J., Koubek, P., Heurich, M., Habel, H. et al. (2001) Distribution and status of lynx in the border region between Czech Republic, Germany and Austria. Acta Theriologica, 46, 181-194.

Wölfl, M. \& Kaczensky, P. (2001) Present status and distribution of the lynx in the German Alps. Hystrix, 12, 39-41.

Worton, B.J. (1989) Kernel methods for estimating the utilization distribution in home-range studies. Ecology, 70, 164-168.

\section{Biographical sketches}

Anja Molinari deals with monitoring issues and the impact of lynx on prey population dynamics. ERIC MARBoutin is interested in the interactions between population dynamics of large carnivores and management-related issues. SY BILLE W ÖLFL's research interests are the human dimensions of large carnivore population recovery. MANFRED WÖLFL deals with implementation of large carnivore management plans. PAOlo Molinari's major interests are the management of conflicts caused by large carnivores. MICHAEL F ASEL is concerned with nature protection and game management. IV AN Kos studies species' composition and their ecological function in forest ecosystems, from invertebrates to large mammals. MATEJA BLAZ̆IC̆ deals with large carnivore issues at the Environmental Agency in Slovakia. Christine BREITENMOSER is involved in research projects on ecology and genetics of the Eurasian lynx. Christian FUXJäGER is concerned with monitoring issues. THOMAS HUBER and IZTOK Koren deal with game management in Austria and Slovenia respectively. URS BREITENMOSER'S main field of activity is the reintegration of lynx into human-dominated landscapes. 